\title{
Listen to the Music: Lessons for Publishers from Record Labels' Digital Debut Decade
}

\author{
Sam Hollander
}

Published online: 4 January 2011

(C) The Author(s) 2010. This article is published with open access at Springerlink.com

\begin{abstract}
Multimedia EBooks present a tremendous growth opportunity for publishers. Yet, industry executives might be cautious after witnessing the astounding collapse of the record business during its digital transition over the last 10 years. This article looks at what went wrong for Big Music, what lessons book publishers can learn from the recording industry's mistakes and also some visions of the future. And why digitally, for books — at least—it can't get here fast enough.
\end{abstract}

Keywords Amazon - Apple $\cdot$ EBook $\cdot$ Barnes \& Noble $\cdot$ iBook Edgar Bronfman, Jr. · Digital · E-Readers · iBookstore · iPad · Kindle · Napster · Steve Jobs · Doug Morris · Warner Music Group

\section{The Change is Gonna Do Me Good-Elton John ${ }^{1}$}

The book business is going through dramatic changes, but the clamor about the paper book being as passé as a piano roll is starting to sound like a broken record.

Considering the sudden disruption of the music industry's business model in the face of the digital revolution, it seems logical for all media executives to tread lightly when faced with their own challenges in this arena; however, a key difference is that the book industry has continued to grow in the download era. ${ }^{2}$ In fact, revenues from book sales have grown at a slow but steady $2.8 \%$ annualized rate in the first full decade of financial results since the introduction of the MP3

\footnotetext{
${ }^{1}$ Elton John, "Honky Cat," Honky Chateau, comps. Elton John and Bernard JP Taupin, 1972 (Universal Songs of Polygram International: Santa Monica, CA).

2 Although there has been a $4 \%$ drop in fiction sales revenues over the last 2 years, increases in textbook and general non-fiction sales revenues have offset such declines.
}

\footnotetext{
S. Hollander $(\bowtie)$

295 Central Park West, New York, NY 10024, USA

e-mail: samhollander@me.com
} 
player. ${ }^{3}$ That growth doesn't even include meaningful EBook sales, which Forrester Research says will reach nearly a billion dollars in revenue in the US in 2010, growing to three billion dollars domestically by 2015. Analyst James McQuivey says, at that point, digital must become the new "default for publishing, preparing for a day in which physical book publishing is an adjunct activity" supporting the digital business. ${ }^{4}$

Less than a year ago, when Apple Inc.'s CEO Steve Jobs announced his "magical" iPad would soon appear, replete with iTunes and iBookstores, he presented the consumer book business with an unprecedented opportunity. ${ }^{5}$ For the first time, there would be a marketplace where books could be designed for distribution and consumption on a single device, pari passu, with movies, television shows, Rock Band games and rock \& roll music - a virtual digital entertainment bazaar. Finally, books will get their meaningful place at the technology table, at least for the time being. ${ }^{6}$

Will publishers embrace EBook technology, instantly downloadable files_- "trick them out" to their fullest potential, and compete in new markets? Or, will they plod along, merely keeping up technologically, while independent and self-publishing sites are constantly the innovators?

Though books about technology abound, books themselves haven't gone through the same degree of technological change, as have other forms of entertainment. In the 133 years since Thomas Edison invented the phonograph, there have been more than a dozen commercially available formats for playing back recorded sound. ${ }^{7}$ In the 555 years since Johannes Gutenberg's Bible, the paperback and the audio book are the only other major advanced book publishing formats besides the EBook.

It's been said that mass media stole generations of readers. That which was once left to readers' imaginations was then given a voice on radio and ultimately a face and maybe even a new ending in movies and television, based on focus groups' feedback. Watching moving images and listening to synchronized sound on a Philco console after a full day of work from a den Barcalounger quickly became a relaxing habit, an easier alternative. Avid readers held steadfast, but for the casual reader, books simply became screenplays yet to be written.

This competition for attention spans is fiercest in the age of instant messaging, IMAX, 3D-TV, Wii and 7.1-surround sound. If publishing companies are to grow the business most successfully with EBook offerings through the iBookstore,

\footnotetext{
3 The first consumer models went on sale in Europe and the US during Christmas 1998. Apple's iPod was introduced almost 3 years later in mid-2001.

4 James MacQuivey, Books May Turn Out to Be the Most Digital of All, Industry Forecast (Cambridge: Forrester Research, 2010).

5 Apple Inc., “Apple Launches iPad,” Steve Jobs Keynote (Cupertino, CA, January 27, 2010).

6 Actually, two technology tables. The iBookstore is a separate download from iTunes-a result of the EU's anti-trust settlement with Microsoft for bundling Internet Explorer into its Windows OS. The EU is looking into iTunes practices, and Competition Policy VP Joaquin Alimnia announced on September 24, 2010 that Apple's relaxed app store policies met with its approval.

7 The piano-roll, the jukebox, the $45 \mathrm{rpm}$, the LP, the $78 \mathrm{rpm}$, the reel-to-reel magnetic tape, stereo, the cassette tape, the 8-track tape, quadraphonic sound, the Compact Disc, SACD/DVD-A and Blu-Ray surround discs, the minidisc and the mp3 are made-it-to market examples.
} 
Amazon and other new digital retailers (like Google), they will need to use the same dramatic techniques in their EBooks and recreate similar stimulating experiences as are employed by television and newer media to attract back these "lapsed readers."

At least one former television news producer vividly recalls The Adventures of Tom Sawyer from the 1973 movie version's first run at Radio City Music Hall, not from the Mark Twain paperback assigned in school. In an earlier attempt to fight the potential loss of casual readers to new storytelling technologies, it was condensedbook expert and magazine publisher Reader's Digest that financed seven successive big-budgeted, annual film releases in the mid-'70's of childhood literary classics with Huckleberry Finn on deck in $1974 .^{8}$

\section{The Future's So Bright, I've Gotta Wear Shades-1986 Timbuk 3 Song'}

EBook hype has now reached unprecedented proportions. Forrester Research forecasts a sunny future in EBook country with expected total unit sales of 12.1 million "dedicated" E-Reader devices through Christmas 2010. If that doesn't sound like a big number, consider that Forrester Research is not including the 60 million-strong installed user base of Apple's mobile iOS4, even though the devices it powers (iPad, iPhone and iPod touches) contain reading apps. ${ }^{10}$ Taken together, the total number of E-Reading-capable devices of various sizes and screens, that are already in people's hands is a much more robust 72 million.

However, Forrester Research is onto something when it comes to dedication. Though the firm says just seven percent of all adults are presently buying EBooks, it points out those seven percent are already buying $41 \%$ of their books digitally and that these "Kindle-connoisseurs" represent the biggest demographic segment of consumer book buyers. ${ }^{11}$ This sets up a very nice network effect in growth terms.

In addition to retailer-agnostic reading devices from Sony, the major booksellers each offer their own private label Kindle-like E-Readers (such as Barnes \& Noble's Nook and Borders' Kobo). Simultaneously, all big retailers also offer cross-platform reading apps such as "Kindle for iPhone" or "BN for Android." Thus, it's clear that the bookstores are trying to keep up with Apple and Amazon as long as possible on hardware (and generate those mobile consumer credit card relationships), while at the same time they are planning for a day when they'll be happy to be selling device

\footnotetext{
${ }^{8}$ Reader's Digest, founded in 1922, and based in Chappaqua, NY, is a general-interest monthly magazine that was the most popular consumer magazine in the United States until 2009 when it was eclipsed by Better Homes \& Gardens. Despite selling over 17 million monthly copies of 50 editions in 21 languages in 70 countries, the company filed for Chapter 11 bankruptcy in US Bankruptcy Court in New York on August 24, 2009. The magazine chopped its frequency from 12 to 10 issues a year and its rate base from 8 million readers to 5.5 million, a decrease of almost $32 \%$.

9 Timbuk 3, "Future's So Bright I Gotta Wea (legal title)," Greetings from Timbuk 3, comp. Patrick Lee MacDonald, 1986 (IRS Music a/c Mambadadi Music Inc.: Santa Monica, CA).

${ }^{10}$ As far as Forrester Research is concerned, hand-held computers such as the iPad and other devices capable of multiple-tasks are not considered "dedicated," though they are functional E-Readers.

${ }^{11}$ Hachette reported 9.5\% of book sales revenues from EBooks in the first 10 months of 2010. The Association of American Publishers announced September 2010 EBooks sales revenues had increased $158 \%$ YOY.
} 
agnostic files. In other words, they can go back to concentrating on what they do well (retail) instead of diverting their energies to something they don't (consumer electronics).

But what happens if, when the dust clears, there are no more chains like Borders or Barnes \& Noble left?

For all the controversy over how to handle EBook pricing by retailers, ${ }^{12}$ the Big Six publishers ${ }^{13}$ will be-as were the record labels before them-powerless to stop the bricks and mortar from crumbling down around the booksellers due to a disrupted business model and sudden woefully inefficient leases. When Tower Records and Sam Goody died, the greatest desires of the big record labels could not resuscitate them.

Forrester Research wasn't always so sanguine about the market opportunities in EBooks. Its December 2000 study, "Books Unbound," was touted by a press release "EBooks Will Flop, But Print-On-Demand And Digital Textbooks Will Thrive, Predicts Forrester Research."

Futurist Nicholas Negroponte, founder of MIT's Media Lab, also sounded the death knell when on August 6, 2010, he told panel moderator CNBC's Maria Bartiromo that the physical book was "dead." Using music as an example, Negroponte reminded everyone that the physical media from his or her youth was outdated. "It's happening. It's not happening in 10 years. It's happening in 5 years," he said. ${ }^{14}$ Whether you agree with Negroponte or not, studying the death by download of the music "business" is worth a Maalox with an Alka-Seltzer chaser. Particularly if you're charged with the task of making content worth what it was before the peer-to-peer relationship came to be considered dirty. Even criminal-as 300 unlucky student Recording Industry Association of America defendants found out.

It may be that of all the entertainment industries, the music business was the most vulnerable to the unsettling forces of the shift from physical to digital media. Song files were small, songs were supposed to be played (it was hoped) repetitively and consumers were habituated to using free, non-physical content on radio. In addition, the punk demographics and interests of the hacker community favored Shawn Fanning coming along before the creator of a peer-to-peer piracy service for book readers. Run from Fanning's dorm room at Northeastern University, the original Napster operated from June 1999 until a court order shut it in July 2001. At its peak, it had 26.4 million users. ${ }^{15}$ Peer-to-peer piracy limits were tested.

Digital media files of all types were always vulnerable to online piracy, but with Napster, Kazaa and other music file-sharing services at server capacity, pirates were, for the first time, materially eating into a major media industry's bottom line. In 1983, US CD sales revenues totaled $\$ 17.2$ million dollars. Just a year later, in 1984,

\footnotetext{
12 Ultimately, the province of the Federal Trade Commission.

13 Reference is to Penguin, Random House, HarperCollins, Hachette, John Wiley and Simon \& Schuster.

14 Nicholas Negroponte, Techonomy Conference (Lake Tahoe, 2010).

15 Jupiter MediaMetrix (July 20, 2001).
} 
they rose six-fold to $\$ 103.3$ million dollars and US CD sales revenues reached a peak of $\$ 12.8$ billion dollars in 1999 .

On the global stage, Napster and its ilk were like pirates on steroids, the Recording Industry Association's worst nightmare. Worldwide CD sales revenues plunged $13 \%$ in 5 years from the record $\$ 38$ billion dollar take in 1999 to $\$ 33.6$ billion dollars by 2004. It was then that an undaunted Edgar Bronfman, Jr., the Seagram scion and former CEO of bankrupt Vivendi Universal Entertainment, along with private equity firms Bain Capital, Providence Equity Partners and T.H. Lee bought Warner Music Group. The sale fetched a whopping \$2.6 billion dollars for divesting Time-Warner CEO Jeff Bewkes. It's not as expensive as it first sounds though, because it was, after all, private equity money. The consortium put down half of the purchase price in cash at closing (much of it borrowed at most favorable rates), which they recouped in a year in a typical leveraged buyout arrangement. ${ }^{16}$ The company went public in an IPO on May 10, 2005 at $\$ 17.00$ a share (NYSE:WMG). At the end of Warner Music's 2010 fiscal year a share in the company traded at around \$4-and-a-half dollars.

Bronfman, a former songwriter, earlier had decided he wanted no part of the beverage business when his turn came to take the reigns at Seagram. So he began transforming the Canadian booze behemoth into an entertainment company. Edgar promptly lost $\$ 3$ billion dollars of the family's Seagram stock value by selling a rising \$9 billion dollar DuPont (NYSE:DD) stake in April 1995 in order to buy, roll up and run Polygram's music assets along with the film assets of MCA and Universal by May of 1998 for a total of \$10.6 billion dollars. He needed a strategic partner in French water utility, Vivendi, which had certain complementary entertainment properties to complete the deal. Edgar arranged for Seagram to be taken over by the French water giant in an all-stock transaction and became the Executive Vice Chairman of the renamed Vivendi Universal. Immediately after the deal was consummated, a scandal ravaged the French utility's stock price and for a second time the Seagram fortune took a hit. Still, Bronfman believes that only by embracing a digital future can the recorded music business return to profitability.

Despite sensationalistic media attempts to portray Bronfman as a dilettante, many say he's a smart man with a passion for music. Certainly no one questions Bain Capital's smarts or private equity's passion for making money. And yet, thus far Warner Music is worth a quarter of its IPO value all the while with Edgar at the helm. In the wake of Bronfman's spectacular fall along with the rest of the music business, it would be foolish to overlook the lessons to be learned from music's digital debut decade if you are involved in the process of making EBooks.

\section{Ambivalence to Change}

Keeping the status quo (the survival of the CD format, in this case) is in itself an understandable strategy for any successful, mature business. But what happens

\footnotetext{
${ }^{16}$ Fred Goodman, Fortune's Fool: Edgar Bronfman, Jr., Warner Music and an Industry in Crisis (New York, NY: Simon \& Schuster, 2010).
} 
when a medium (music) is mature, but its distribution channel evolves faster than a concurrent business model? The label chiefs learned the answer to this question the hard way-imbued with false bravado, the industry leaders reacted clumsily and defiantly. As they fought for each piece, they hadn't even realized they had lost the war.

After observing the digital carnage, it's no wonder Hollywood, the TV networks, and now book publishers have waded lightly into these digital waters. Mobile distribution is just another pay window in an audio-visual work's revenue stream. But for book publishers, the opportunities exist for new products and categorieseven entering markets typically thought of as the domain of others, such as producing media rich documentary titles and taking on Discovery, Nat Geo TV or the network news divisions.

\section{Artwork/Packaging}

When Big Music transformed into $120 \mathrm{~mm}$ diameter compact discs, it destroyed the iconic value of album art. Retailers like Sam Goody and Tower Records refused to invest the cost needed to retrofit stores based on the new format. Thriftily, the labels decided on using half empty $6 " \times 12$ " "long-boxes" so two CDs could fit sideby-side in the same bins as LPs. They still preserved a "slice" of album art, but the damage was done. Later, opportunities to include screen-savers or lyrics in download files were wasted.

Rather than contribute to the cost of bespoke CD displays or work towards a long-term art and store friendly solution, the labels took the short-term approach to long-run damage. It's important for EBook publishers to learn from these missteps and exploit the heck out of the graphics capabilities of the EBook download file.

Initially retailers displayed CDs in plastic "jewel" boxes to give the CD the futuristic sheen justifying its futuristic price, which included the 30-cent cost of the "jewel box." Artists and consumers initially grumbled about this plastic packaging because it was non-recyclable. Later, packaging protests picked up-this time consumer and artist versus the labels over the conspicuous waste in the cost of the "jewel box." And guess what? Recyclable and cheaper, cardboard carried the day.

Many in the book industry are sensitive to the issue of production costs and more than a little sympathetic to the label's desire to use packaging to keep retail prices high. More than a few senior digital publishing execs say the industry needs to do a better job of communicating to the public that it is expensive to produce an EBook. Such expenses they say offset any savings from print runs. Is the book business prepared for a PR campaign aimed at convincing the public that EBooks should not be de facto cheaper while readers become aware that all of the flops in the remainder bins they see on display at their local bookstore are really on consignment, headed for the city dump?

EBooks, as a supply and inventory chain control, save trees. Dr. Seuss's The Lorax may speak for authors and readers as well as the trees. This may be a battle best not fought in a green economy. 


\section{If You Don't Know What They're Talking About, Hire People Who Do}

Universal Music chief Doug Morris fancies himself a "hit maker" not some "tech geek." He's paid to top the charts. To do so, he is also paid enough to get others to do what he'd rather or cannot do. As he puts it, by way of explanation or excuse, "I wouldn't be able to recognize a good technology person. Anyone with a good... story would've gotten past me." ${ }^{17}$ But the pertinent question isn't "who got past him?" But, "who never got in to see him?"

In the 1990's it behooved the longtime label titans like Walter Yetnikoff, Clive Davis $^{18}$ and Doug Morris not only to pay a "tech geek" or twelve, but also to listen to them as well. There were noted technologists at some labels such as Sony Music's Mark Ghuneim, but how much credence was given to their recommendations? If you're a publisher, it's not whom you are seeing but whom you are not that's cause for concern.

\section{Build Communities}

Record Companies have not been terribly creative about the ways they've gone about connecting listeners to communities organized around music artists. They've done little more than sign-up fans to alert them to new product or tours. Simultaneously in many cases, the artists maintain their own "e-mail" connections, fan club sites on Facebook and other social media.

Publishers ought to take a cue from the musical artists here and take an active approach to building communities around authors and titles. The right to operate an author website should be up for negotiation like anything else, but if I had the scale of a publisher why wouldn't I make e-commerce part of my long-term bet on a would-be bestselling author?

It may just be that this arena was never negotiated and has fallen through the cracks with each party exploiting the artist website from their own perspective, but this is a loophole that should be plugged.

To give you an idea in a different industry of the kinds of loyal dollar-laden traffic artist sites attract, take a look at the membership numbers of sites of hosts in talk radio (where some syndicators have seemingly waived their rights: Rush Limbaugh...16 million registered users. Laura Ingraham...6 million). Has that ship sailed with your authors at the rudder?

Content engagement tools such as comment and rate applications that are widely used to enable "sticky" websites can be deployed along with social media to bring together those readers of a particular title. Upon opening the EBook file, the reader could be asked whether they are in a book club or whether they wish to join one. The reader who's already in a club supplies the email addresses of other club members and those who wish to join one are automatically placed in one by the

\footnotetext{
17 Seth Mnookin, "Universal's CEO Once Called iPod Users Thieves. Now He's Giving Songs Away," Wired, November 27, 2007.

18 Longtime heads of CBS/Sony and Arista Records.
} 
Publisher. Real-time commenting or chat could also allow readers to see what fellow book club members have to say about the noted passages.

\section{Always be Signing}

Record companies made so much money from people replacing their albums with CD versions, the soaring 80's-90's revenue figures masked the fact that Artist \& Repertoire wasn't as active as it used to be. Thus, after a small uptick in music popularity at the turn of the century due to boy bands and Britney Spears, record companies were bereft of new acts. Editors must constantly look for new talent. New talent will be just as important in the future. No matter what that is.

\section{Multimedia Support}

How did record labels cross-sell? The labels' joint marketing efforts (through the Recording Industry Association of America) focused more on eliminating piracy than making its product digital friendly. Consequently, you were as likely to hear a list of liabilities as one of product benefits.

Publishers have smartly used television as a marketing technique in the past. (Oprah's book club and use of TV news magazines like 20/20 for example) and will have the opportunity to utilize the audio and visual tools of television to lure back those lapsed readers who were distracted away by mass media.

\section{Sponsors}

Presently, and as a direct result of declining music sales, advertisements or product placement are common in exploiting synchronization rights in music. Hence, the proliferation of songs in ads as well as use of tracks in movies or on TV shows. None of the sources in digital publishing would agree that in-book advertising is on the horizon. At the same time, one top digital officer noted that the cost of producing EBooks is higher than the public believes and confessed that, "we don't do enough to communicate that." Despite the present denials, look for "sponsored by..." EBooks. Publishers will not be able to resist the money and given the public's desire for lower prices and the recent return of sponsored programming to TV and product placement in movies as well, consumers are prepared for this.

\section{Label-Run Stores}

Publishers wisely did not waste 3 years before agreeing to a functional legal book download service, as did self-absorbed record labels who suddenly decided to be retailers as well. Your bands are your brands. Some labels including Sony had at least two non-exclusive primary sales sites before relying on iTunes for the crux of 
their online sales. ${ }^{19}$ Did they ever ask themselves, "Does a fan know that Bruce Springsteen is signed to the Sony label?" And more importantly, "Is that how she decides where to shop, by record label?"

\section{Format Wars}

Part of the reason why the marketing of the compact disc took off was due to the existence of the Compact Disc working group with representatives from the labels and hardware manufacturers. This obviated the need for multi-format compatibility. Every CD worked in every player. Unfortunately, that experience has not been repeated with DVDs and certain discs won't play on certain players. The Kindle uses a proprietary format.

\section{No Digital Rights Management}

Part of the enjoyment of content is sharing that experience with friends. The record industry used various Digital Rights Management (DRM) systems to control copying, the most popular being Apple's Fairplay system (which allows for the use of purchased downloads on no more than five computers). As people regularly began to add iPods and streaming TV devices to their collection of gadgets, labels realized even Fairplay's limits would become widely exposed. EMI became the first label to strip its downloads of any protection for an additional 30 cents at retail. By April 7, 2009 all music in the iTunes store was DRM-free. ${ }^{20}$

While DRM-free sounds like a great path for EBooks to follow, ${ }^{21}$ it's not the case when one stops to consider the two most common ways readers acquire books today: (1) on loan from friends and (2) borrowed from a library. ${ }^{22}$ Thus, much of the book business is already free. And, it is still profitable.

"It will never receive the attention it deserves for a multitude of reasons, none of which have anything to do with the song or the band, but with the complete shambles that is the music industry."-Music critic Darren Robbins on 2010 Crowded House single, Twice if You're Lucky. ${ }^{23}$

The Book industry, unlike the record business, is not in shambles. Far from it. Furthermore, areas that are growing in popularity play right into certain of EBook's strengths, such as access to footage associated with release of a derivative work and

\footnotetext{
19 Sony's Connect and Pressplay were two examples.

20 iTunes is currently the largest music retailer in the world and on February 24, 2010 served up its 10 billionth download.

21 Amazon began to pave that path on October 10, 2010, when it announced Kindle readers would be allowed to "loan" Kindle books to friends for 14 days.

22 James MacQuivey, Books May Turn Out to Be the Most Digital of All, Industry Forecast (Cambridge: Forrester Research, 2010).

23 Darren Robbins, Album Review: “Intriguer by Crowded House," June 14, 2010, www.zeitgeisty report.com.
} 
the ability to satisfy an impulse purchase of a topical book based on a consumer hearing about it on a television program. ${ }^{24}$ The fiction category's decline seems to be the only problem area and that tends to be cyclical and can be solved by focusing on the reader (See: Always Be Signing). By learning from the mistakes of the music business, multi-media laden nonfiction "newsbooks" and books-made-into-movies will win back "lapsed readers" ensuring publishers have customers for generations.

Remember that former television news producer? Now let us imagine it is 2013 and that his son is assigned The Adventures of Tom Sawyer in school. He downloads an EBook version directly onto his tablet, enhanced with a famous Lit professor's audio comments, local footage of the Mississippi river in the 1900's, a video biography of Samuel Clemens and the famous painting scene from the movie version his father liked so much. He does not go to the movies. Maybe the boy does the most 21 st century thing of all: along with watching and listening-he reads.

Open Access This article is distributed under the terms of the Creative Commons Attribution Noncommercial License which permits any noncommercial use, distribution, and reproduction in any medium, provided the original author(s) and source are credited.

\footnotetext{
${ }^{24}$ When a random series of lapsed readers were asked for the type of book they last bought and the motivation for the purchase, far and away the most popular responses were: books made into recently seen movies and nonfiction in the news.
} 